\title{
The human resources crisis in South Africa: challenges and opportunities for business
}

\author{
F. Grant Schutte \\ School of Business Leadership, University of South Africa, Pretoria
}

In view of the importance of the human asset to the South African economy, the major crises facing South African managers in the human resources area are discussed, together with possible solutions to these problems. The six major components of the human resources crisis, as perceived by the author, are related in a matrix to 11 major challenges or opportunities for management, in the handling of these problems. The crisis components discussed are: actual and potential large-scale black unemployment; a shortage of skilled and semi-skilled labour; a shortage of supervisory and middle management; socio-political wage pressure; strikes; and problems relating to cultural differences. The challenges facing business include: the promotion of entrepreneurship; developing greater understanding of cultural differences; development and retraining; skills training; selling the free enterprise system; the creation of jobs; effective delegation, communication, control and feedback; improved union negotiation; improved industrial relations; increased productivity; and the development of strategies and plans to prevent a greater crisis.

S. Afr. J. Bus. Mgmt. 1982, 13: $45-52$

In die lig van die belangrikheid van die menslike bate vir die Suid-Afrikaanse ekonomie, word die belangrikste krisisse wat op Suid-Afrikaanse bestuurders op die gebied van menslike hulpbronne wag, bespreek, tesame met moontlike oplossings vir hierdie probleme. Die ses belangrikste komponente van die krisis, soos deur die skrywer gesien, word in 'n matriks in verband gebring met 11 groot uitdagings of geleenthede vir bestuur in die hantering van dié probleme. Die volgende krisiskomponente word bespreek: werklike en potensiële groot. skaalse swart werkloosheid; ' $n$ tekort aan geskoolde en halfgeskoolde arbeid; ' $n$ tekort aan toesighoudende en middelbestuur; sosio-politiese loondruk; stakings; en probleme weens kultuurverskille. Die uitdagings vir die sakewêreld sluit in: die bevordering van entrepreneurskap; ontwikkeling van groter begrip van kultuurverskille; ontwikkeling en heropleiding; opleiding van geskoolde werkers; die bemarking van die vryemarkstelsel; skepping van werksgeleenthede; doeltreffende delegering, kommunikasie, beheer en terugvoering; beter vakbond-onderhandeling; beter arbeidsbetrekkinge; verhoogde produktiwiteit; en die ontwikkeling van strategieë en planne om 'n groter krisis af te weer.

S.Afr. Tyoskr. Bedrytsl. 1982, 13: 45-52

Paper delivered at Inauguration Seminar of the Barclays Centre for Business Studies, Sandton, Johannesburg, March 8, 1982

Prof. F.G. Schutte

Director, School of Business Leadership, University of South Africa,

P.O. Box 392, Pretoria 0001, Republic of South Africa

\section{Introduction}

'One hears a great deal about South Africa's mineral wealth and the importance this has both for this country and for the West. One hears about our agricultural production which is the highest in Africa, our technological advances, our manufactured goods - even the armaments we are now producing ourselves. Yet we are inclined to forget that man, the worker, is the pivot, and that without his energy and industry none of this would be possible."

This quotation, taken from a speech delivered by the Honourable Mr S.P. Botha, Minister of Manpower Utilization, in 1980, crystallizes the importance of the human asset to the economy of South Africa. Without the recognition and development of this asset, the natural resources of South Africa would amount to nothing. For this reason, it is crucial that we consider the various crises at present confronting us in the human resources area, and seek solutions to the problems facing us.

Perhaps, initially, I should clarify what I mean by 'human resources crisis' within the context of this discussion. By 'human' I mean 'that which relates to man' not only in terms of numbers and behaviour but also in terms of individual experience. For example, in our examination of strikes, we must not only look at the numbers of strikes and the behaviour of workers during those strikes; we must also look at how the individual experienced the various situations which led him to take strike action. By 'resources', I refer to a stock which can be drawn on; an available asset. By 'crisis', I refer to a critical moment of disequilibrium, a breakdown in the process of, in this instance, production. If one considers labour, capital and material resources as the three major variables of production, one can understand the crisis in terms of a breakdown in the relationship between these three. The reasons for such a breakdown lie, moreover, not only in the structure of South African society (that is, in a racially-divided system which through historical legislation has given rise to problems such as unequal education, wage discrimination and unemployment specifically in the human-resources area), but also with management, the regulators or co-ordinators of the variables of production.

We shall concentrate on the breakdown in production with specific reference to the stock of people available to the South African economy. I shall mention only six (of 
the many) interrelated components of the human resources crisis which give rise, I believe, to 11 major challenges and opportunities for business - for management - in the short term. Although one must obviously look to the broader political structure of South African society in order not only to understand these problems but also to seek their ultimate remedy in the long term, I shall concentrate on the challenges and opportunities they present to business in the short term. The six major components of the human resources crisis are: actual and potential large-scale black unemployment; a shortage of skilled and semi-skilled labour; a shortage of supervisory and middle management; socio-political wage pressure; strikes; and problems relating to cultural differences.

We shall consider each of these components, and then discuss the challenges and opportunities open to business with respect to their remedy. These are set out in the matrix in Table 1. The six main components of the crisis are listed along the horizontal axis and the 11 major challenges and opportunities for business along the vertical axis; and the matrix highlights the relationship between the two.

\section{Some major components of the human resources crisis}

Actual and potential large-scale black unemployment

One of the major characteristics of South Africa's labour force is its racially-divided nature. Approximately $70 \%$ of the economically-active population of South Africa is made up of black workers, ${ }^{2, p .1 .1 .1}$ the majority of whom are semi-skilled, unskilled or unemployed. Indeed black workers constituted the majority of the 1943222 unem- ployed and underemployed workers in $1977 .{ }^{3}$ As estimates indicate that the economically-active population of South Africa will have increased from 8714000 in 1977 to 11833000 by 1987 - an increase of approximately 267000 workers per annum -730 job opportunities will have to be created each day for the whole of that 10-year period to keep pace with the increase in the labour force. In view of the fact that realistic forecast suggests that job opportunities will increase from 5344000 to 7005000 from 1978 to $1987,{ }^{4}$ it can be seen that unemployment will grow. Such unemployment can, moreover, be expected to occur disproportionately among those lacking in skills and education.

\section{A shortage of skilled and semi-skilled labour}

Together with a relatively high rate of unemployment, South Africa is also suffering from a severe skills shortage. Skilled jobs and the more highly-qualified occupations are at present almost entirely the domain of the whites, while approximately $90 \%$ of the economicallyactive black population is to be found in semi- and unskilled occupations. ${ }^{5}$ However, Dostal ${ }^{6}$ predicts a shortage of 705000 skilled workers in 1981, and of 1330000 in 1990. Similarly, Sadie' calculates the required gross annual additions to the highly-skilled and less skilled categories of the labour force of persons other than whites as follows:

Highly skilled

Less skilled

\begin{tabular}{ccc}
$\begin{array}{c}\text { Actual } \\
1959-1979\end{array}$ & $\begin{array}{c}\text { Projected } \\
1980-2000\end{array}$ & $\begin{array}{c}\text { Acceleration } \\
\text { rate }\end{array}$ \\
\hline 8000 & 43000 & 5,4 \\
18000 & 52000 & 2,9
\end{tabular}

Table 1 Crisis/Challenges and Opportunities Matrix

\begin{tabular}{|c|c|c|c|c|c|c|}
\hline $\begin{array}{l}\text { CHALLENGES } \\
\text { AND } \\
\text { OPPORTUNITIES } \\
\text { FOR BUSINESS }\end{array}$ & 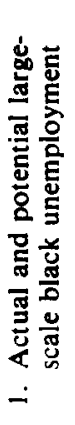 & 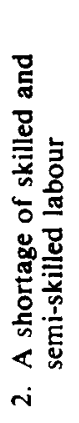 & 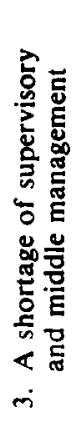 & 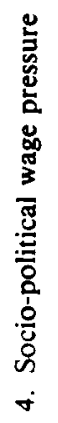 & 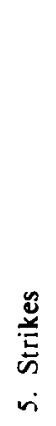 & 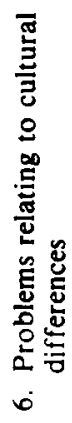 \\
\hline 1. Entrepreneurships & レ & & & レ & & V \\
\hline $\begin{array}{l}\text { 2. A greater understanding of cultural } \\
\text { differences }\end{array}$ & & & レ & & レ & $V$ \\
\hline 3. Development and retraining & & & V & & $\checkmark$ & レ \\
\hline 4. Skills training & $レ$ & レ & & レ & & \\
\hline 5. Selling the free enterprise system & & & & & レ & レ \\
\hline 6. The creation of jobs & $\checkmark$ & & & & V & \\
\hline $\begin{array}{l}\text { 7. Effective delegation, communication, } \\
\text { control and feedback }\end{array}$ & & & レ & レ & & $レ$ \\
\hline 8. Union negotiation & & $レ$ & & & レ & $\checkmark$ \\
\hline 9. Industrial relations & & $レ$ & & & レ & レ \\
\hline 10. Increased productivity & & $\checkmark$ & & $V$ & & V \\
\hline $\begin{array}{l}\text { 11. The development of strategies and } \\
\text { plans to prevent a greater crisis }\end{array}$ & レ & $レ$ & レ & レ & $レ$ & レ \\
\hline
\end{tabular}


These figures highlight the need to reduce this shortage of skills by moving more black people into the skilled occupational group. Such movement in turn could lead to a higher rate of economic growth which is necessary both for the creation of employment opportunities, and for a narrowing of the wage gap between skilled and unskilled whites and blacks. According to the November 1980 estimates of Mercabank, ${ }^{8}$ an increase in skilled labour of $3,2 \%$ per annum is required to sustain a growth rate of $5 \%$ per annum.

\section{A shortage of supervisory and middle management}

The occupational structure in South Africa is at present characterized by its 'bottom-heavy' nature, with 28 unskilled, 29 semi-skilled and five skilled workers employed for every one executive. ${ }^{2}$ In other words, one manager exists for every 42 workers in South Africa, our closest comparison being Australia where the ratio is $1: 11$. Whereas in South Africa 5,5\% of the economically-active population falls into the category 'professional, technical, administrative and managerial workers', the corresponding figures for the UK and USA are 14,7\% and $24,7 \%$ respectively. ${ }^{9}$ Moreover, the vast majority of occupants of these higher-level positions are whites, with blacks accounting for no more than $1,64 \%$ of the positions in the category 'managerial, executive and administrative employees'. ${ }^{10}$ This is in spite of the fact that the required gross annual additions to the executive category of the labour force of persons other than whites have been estimated as follows: ${ }^{7}$

\begin{tabular}{cccc} 
& $\begin{array}{c}\text { Actual } \\
1959-1979\end{array}$ & $\begin{array}{c}\text { Projected } \\
1980-2000\end{array}$ & $\begin{array}{c}\text { Acceleration } \\
\text { rate }\end{array}$ \\
\cline { 2 - 4 } Executive & 300 & 3800 & 12,7
\end{tabular}

The shortage of supervisory and middle management is acute, not least because of the lack of trained black manpower to fill the posts available.

\section{Socio-political wage pressure}

Although there is no legislation which prescribes discrimination in remuneration or which legislates as to the amounts payable to specific groups, two significant wage gaps between whites and blacks exist in many organizations at present. These have been well set out by Rosholt:"1

Discrepancies in the pay scales of people doing the same jobs carrying the same responsibilities. One cannot escape from the fact that blatant wage discrimination could have serious repercussions in the not too distant future although, for many of us, it already constitutes a humanitarian crisis at present.

The artificial discrepancy between the wages of those in unskilled occupations - mainly black people - and the salaries of those in occupations requiring greater skill. This wage gap also represents a crisis inasmuch as its existence retards the development of blacks who could aspire to higher positions. Thus, an integrated pay structure is perhaps the only solution. The problem, of course, is how to institute a fully-integrated pay structure in labour intensive organizations; increased wages demand greater efficiency and greater productivity if such organizations are to remain viable. ${ }^{\prime \prime}$

\section{Strikes}

Figures relating to strike activity suggest an exponential rise in the number of strikes which have taken place in South Africa during the last two and a half years. For example, 36 strikes occurred in 1979, 61 between January 1980 and the end of August 1980, and 80 between September 1980 and June $25,1981 .{ }^{12}$ Ninety percent of the labour unrest has involved black workers and one has to concede that political issues have, and will increasingly become, inextricably intertwined with economic issues in those trade unions which represent black workers.

\section{Problems relating to cultural differences}

In the wake of the recommendations put forward by the Wiehahn Commission, and with increasing pressure from international companies for the abolition of job reservation and for the institutionalization of equal job opportunities for all, much has been said and written about the problems confronted by the non-white manager, and in particular the black manager, within the South African context. Emphasis has been placed both on the extent to which the abilities and the performance of the black manager in the work situation are influenced by his traditional culture and on the barriers confronted by black people in the actual work setting. ${ }^{13}$ This latter perspective has investigated issues such as tokenism or window dressing, white attitudes towards the promotion of black people and those of the white managers with whom the black managers are in closer contact. ${ }^{14}$ Similarly, the behaviour of the black manager in the work situation in South Africa is reasonably well documented. Hofmeyr, ${ }^{3}$ of the UNISA School of Business Leadership (SBL), in his interviews with senior-(white) line management, firstline (white) managers and potential black managers found, inter alia, that black managers are generally regarded as finding leadership, responsibility and autonomy problematic. They tend to be subservient, to experience problems in communicating clearly, to be insufficiently at ease with business concepts, to generate some customer resistance, to be affiliation-oriented and to lack interpersonal skills. Nasser, ${ }^{15}$ also of the SBL, suggests that the performance of the black manager is handicapped by an inability to function autonomously and to handle increased responsibility, a lack of selfassertion, a tardiness in decision-making, a low propensity for risk-taking, a lack of innovation and creativity and, finally, a lack of initiative in resolving problems.

In general, the underperformance of certain black managers has been attributed to three main sets of factors, namely, cultural factors, educational factors and discrimination. However, although the problems relating to such factors do, undoubtedly, constitute an issue of critical importance within the South African context, recent research undertaken at the School of Business Leadership suggests that our failure to understand and explain the experiences of the black manager in a white world constitutes a crisis of equal import. ${ }^{16,17}$ Unless we begin to understand the experience of the black manager 
and to seek alternative solutions to his dilemma, the problems relating to cultural differences will continue to expand and grow.

We shall now consider the challenges and opportunities that arise from these six components of the human resources crisis, and discuss how each challenge and opportunity in turn can ameliorate certain aspects of that crisis.

\section{Some major challenges and opportunities for business}

\section{Entrepreneurship}

One of the major challenges open to business at present is the creation of a climate within which a spirit of entrepreneurship can re-emerge. Job security, a high standard of living (which many white managers feel they must, at all costs, maintain) together with an organizational climate of over-control and red tape are all factors which breed out entrepreneurship and which breed riskavoiders. During the course of research recently undertaken by the School of Business Leadership, ${ }^{17}$ clear evidence was found of the tedium felt by many managers, especially those employed by large organizations, with respect to the bureaucracy, red tape and lack of clarity with which they are confronted daily. The challenge open to business lies in delegation; we must force decisions at lower levels of management and then learn to accept decisions which are not necessarily the same as ours would have been. In other words, lower and middle management must learn to be situationally creative in their management. They should also be made conscious of the fact that they have the right to be wrong or to be different. If we allow our managers to 'do things their way', they will rise to the occasion and a spirit of entrepreneurship will be rekindled. ${ }^{18}$ Perhaps a further area open to investigation constitutes the structure of business school courses. It may well be that the way in which courses are structured and presented also stifles entrepreneurship. A challenge to business school management lies in a reassessment of the content and structure of their courses with a view to bringing a spirit of entrepreneurship "back in'.

With respect to black managers and entrepreneurs, specifically, it would appear that South Africans are, at present, doing everything possible to stifle every ounce of entrepreneurship that exists! In recent studies of black managers, the SBL found that the position of the black manager within many organizations is circumscribed to the extent of providing him with very little opportunity to do things in his way. In essence, we are so busy trying to change the black managers to fit the white mould that we destroy their entrepreneurial talents in the process. The challenge open to business lies in asking whether we should be attempting to change people to fit jobs or if, rather, we should be changing our jobs and our schedules to fit the motivational patterns of specific individuals. Put simply, perhaps one of the main challenges open to business lies in the incorporation of some aspects of all of our various cultures into the work environment. ${ }^{17}$ The meeting of these challenges could solve some of the problems relating to cultural differences (component 6 on the crisis axis of the matrix), could increase productivity to justify wage increases (component 4 on the crisis axis of the matrix) and could eventually lead to a reduction in unemployment (component 1 on the crisis axis of the matrix).

Turning to black businessmen, it would appear that, although black entrepreneurs have now been given a far greater opportunity to participate in the free enterprise system than before, entrepreneurship has, until recently, been effectively stifled by a tangle of rules, regulations and legislation. Moreover, black businessmen in South Africa are often undercapitalized because of difficulties in obtaining funds; they are therefore unable to buy in bulk which leads to higher prices and a limited range of commodities; this, in turn, leaves them unable to compete with white stores for customers and profits are consequently small. Many black businessmen also lack managerial know-how and training and their entrepreneurial attitudes often conflict with traditional values. ${ }^{19}$

In the years ahead, a far greater emphasis will have to be placed on the development of business skills and the promotion of the informal business sector. The challenge for business lies in its active support of programmes designed to bring black entrepreneurs into the mainstream of the free enterprise system and to overcome the unique problems with which the black entrepreneur is faced. This in turn could lead to a reduction in unemployment and assist in the amelioration of many of the problems associated with cultural differences (components 1 and 6 on the crisis axis of the matrix).

\section{A greater understanding of cultural differences}

In the SBL's recent research among almost 300 managers from all over South Africa, we became aware of three distinct profiles, namely, that of the white Afrikaansspeaking manager, that of the white English-speaking manager and that of the black manager. These profiles have, moreover, led us to conclude not only that differences between these three main types of manager may well exist on a general level, but also that such differences should be conceded to and even acted upon.

For example, the white Afrikaans-speaking manager is more likely than other South African managers to be reasonably confident of his own ability and to judge others in the work situation in a critical, objective way. He appears not to worry overmuch about what others think of him and tends to welcome situations in which he can do things in his way with minimal interference. He dislikes red tape, bureaucracy and administration and often regards his superiors, colleagues and subordinates as incompetent, ignorant or narrow-minded. He is happy when his top management and immediate superior do not interfere in his work and when a good team spirit exists between himself and his colleagues and subordinates.

The white English-speaking manager is likely to be a little 'softer' and a little less critical than his Afrikaansspeaking colleague. He is also reasonably confident of his own ability but tends to show more respect for the attitudes and opinions of others and to care rather more about what others think of him. He appreciates support and flexibility and welcomes mutual respect and a free exchange of ideas. He tends to dislike autocratic and inaccessible superiors and tries to be co-operative in his relationships with colleagues doing similar work. He worries about his subordinates when they lack motivation and is 
gratified by their development and growth.

Like the white English-speaking manager, the white Afrikaans-speaking manager is likely to feel that the most crucial differences between managers of different races relate to the influence of culture and upbringing on performance in the work situation. With respect to differences between white managers, however, he is likely to regard himself as less professional but as more authoritarian than the English-speaking manager while the latter is likely to regard the Afrikaans-speaking manager as conservative.

The black manager is more likely than the white South African manager to be sensitive to the need for adequate and meaningful relationships in the work situation; he demands feedback and the accessibility of superiors and thrives on satisfactory communication. He needs to know where he stands, to be shown respect and to be appreciated and encouraged. The black manager is more likely than the white South African manager to assess his relationships with superiors, colleagues and subordinates in a subjective way; that is, he frequently does not assess the performance of his fellow employees objectively - at a distance from their relationship with him; rather, he assesses other employees in terms of the way they seem to feel about him. The black manager is, for example, more likely to worry about whether or not his subordinates show him respect than about how they are doing their job. Similarly, the black manager is more likely than the white manager to obtain satisfaction from interpersonal contact and from customer satisfaction. He is also more likely to thrive in a relationship with a supportive and committed immediate superior, and to be demotivated by overtones of racism or simply poor communication in his relationships with his colleagues.

Although most managers - both white and black regard themselves in a favourable light, the black manager is generally extremely positive about his own self-image and is more likely than the white manager to feel that his potential has been achieved. He is, however, likely to concede that increased knowledge and education will make him better at his job. The black manager, like his white Afrikaans-speaking counterpart, is more committed to South Africa than the white English-speaking manager. For this reason, he would tend to think long and hard before accepting a position overseas.

The black manager is likely to attribute 'racial' differences to the broader socio-political context and to its differential treatment of black people and he may also be suspicious of white managers: of the Afrikaner for his occasional racism and of the English-speaking manager for his occasional hypocrisy.

That so many differences among managers exist is perhaps a point worthy of some consideration - a challenge - for business. Should we not attempt to do away with dubious and fictitious stereotypes and allow people to do their jobs in a way which comes naturally to them? The challenges for business are to consider taking cognizance of the various fundamental structures of experience which exist among managers, to tolerate individual needs and goals and, again, to incorporate some aspects of all of our cultures into the work environment. ${ }^{17}$ The meeting of these challenges could, in turn, facilitate the movement of black people into supervisory and mid- dle management (component 3 on the crisis axis of the matrix) and could draw more black people into a satisfactory relationship with the free enterprise system thereby reducing strike activity and problems relating to cultural differences (components 5 and 6 on the crisis axis of the matrix).

\section{Development and re-training, and skills training}

The third challenge for business lies in the development and re-training of its workforce, activities which are linked to a fourth challenge, namely, skills training. A predecessor to all of these activities is, however, education, a commodity which is at a sadly low level among certain segments of the population in South Africa today.

For example, in 1979, for every R724 spent on one white pupil, R7I was spent on his black counterpart and whereas for every 20 pupils one teacher could be found in most white schools, the teacher/pupil ratio in black schools stood at 1:48. Similarly, whereas $97 \%$ of the teachers in white schools were educated at least to matriculation, the corresponding percentage in black schools in 1976 was $15,5 \% .{ }^{3.20}$ In 1970, whites accounted for $90,9 \%$ of all of the standard 10 passes and $95,5 \%$ of all degrees in South Africa. ${ }^{3}$

It goes without saying that both quantitatively and qualitatively the black education system is at present grossly inferior to that of the whites. For this reason, one hopes that the ultimate response of the government to the De Lange Report on Education will be of some significance. However, while the long-term onus for general education must clearly rest with the government, business, in the short term, has its part to play, not least because educational improvements will be beneficial to business."

The challenge for business is to provide basic educational courses for its illiterate employees together with extramural educational facilities for those employees' children who require or desire extra tuition. Business should also augment the provisions now being made and envisaged by the public sector for the expansion of facilities and opportunities for technical and professional training; the challenge for business is to institute programmes of in-service training and re-training and to supplement these services through the institution of commercially-run educational training programmes. ${ }^{21}$

Development and re-training could help to alleviate the shortage of supervisory and middle management (component 3 on the crisis axis of the matrix) as well as to reduce the number of strikes by, inter alia, an increase in pay commensurate with an increase in skills. A reduction in the wage-gap with an increase in skills would, in turn, help to alleviate some of the gross discrepancies in pay at present associated with race (components 5 and 6 on the crisis axis of the matrix). Skills training could further reduce unemployment, facilitate a reduction in the shortage of skilled and semi-skilled labour and play a part in a move towards a more integrated wage structure (components 1,2 and 4 on the crisis axis of the matrix).

\section{Selling the free enterprise system}

'The free enterprise system' is a concept which is taken for granted by most whites in South Africa but which is 
very poorly understood by most black people, irrespective of educational level. In view of the increasing awareness, particularly among black people, of the existence of other systems in conflict with our own, it is crucial that business meets the challenge of selling the free enterprise system to its employees. In other words, employees must not only be made aware of how the free enterprise system works but also of its benefits to the individual. An awareness of and commitment to the free enterprise system could reduce the number of strikes and solve some of the problems relating to cultural differences (components 5 and 6 on the crisis axis of the matrix).

\section{The creation of jobs}

As stated earlier, in order to keep pace with the growth of the economically-active population, 730 job opportunities would have to be created each day for the 10-year period $1977-87$. Such is the need for jobs! The challenge for business is to reduce unemployment and to draw black people into the industrial system, not only in order that some of their needs and aspirations may be met but also to offset, through training, the possibility of mass action by the unskilled. In order to do this, business must look for ways of trading off capital in favour of labour in the short term with a view to creating a higher level of skill and capital intensity in the long term. The meeting of this challenge - the creation of jobs - would not only reduce unemployment, but would also draw more black people into the free enterprise system within which labour unions can work in conjunction with business in striving towards a mutually advantageous relationship. Indeed, the greater the unemployment, the smaller the level of unionization and the greater the possibility of uncontrolled and uncontrollable social unrest among the disadvantaged. It is the responsibility of business to engage as many South Africans as possible in active employment, for the benefit of all.

\section{Effective delegation, communication, control and feedback}

The seventh challenge for business is the development of effective management systems not only to improve profitability but also to improve the quality of work life of employees - both on a general level and on a specifically 'black' level. An effective management process will not only lead to the creation of enriched entrepreneurial roles and to a highly-motivated management team at all levels, but will also solve some of the problems currently confronted by black managers within the work environment.

On a general level, for the management process to be effective, the organizational design and the responsibilities of individual managers in the managerial hierarchy must be clearly specified and understood; planning, control and information systems have to support individual managerial responsibilities in an integrated manner and, finally, performance measurement, development and reward systems have to be integrated and supportive to the management process. ${ }^{18}$ An effective, integrated management system, in turn, should overcome the blunting effects of the red tape, bureaucracy, duplication and confusion mentioned so frequent- ly by managers during the course of our research. ${ }^{17}$

With respect to the inconsistencies, ambiguities and conflicts confronting the black manager in a white organization, the definition of key performance areas would give him a clear idea of his roles and responsibilities $v i s-\grave{a}-v i s$ those of other managers, and charges of discrimination or window-dressing could thus be dismissed. Moreover, a standard evaluation procedure could be developed with respect to the key performance areas of all managers. Evaluations would, however, have to be discussed with the particular managers concerned in order that these may be seen as reasonable and objective and as void of any discriminatory overtones. Black managers could also be placed in the care of sympathetic mentors who would attempt to share the burden of the machinations of the informal organization. ${ }^{16}$

In this regard, Jones, in describing his experiences of 'What it's like to be a black manager' in the USA, suggests an appraisal of managers on their contributions to the company's equal-opportunity objectives. According to Jones, ${ }^{22}$ 'The entire management team must be motivated to change any deep beliefs about who does and doesn't fit with regard to colour. Accordingly, companies should use the appraisal system to make the welfare of the black trainee coincident with the well-being of his superior. Such action, of course, will probably receive considerable resistance from middle- and lower-level management. But managers are appraised on their ability to reach other important objectives; and, more significantly, the inclusion of this area in appraisals signals to everyone involved that a company is serious. Failure to take this step signals business as usual and adds to any credibility gap between the company and black employees'.

Moreover, this kind of appraisal system motivates the mentor to school the black trainee in the realities of the political process in the organization. According to Jones, no one can survive in an organization without this kind of information. Jones also suggests unquestionable topmanagement involvement in and commitment to well thought-out plans of equal opportunity and direct twoway channels of communication between top management and trainee black managers. With regard to the latter, it would appear that Jones is tacitly recognizing a problem particularly pertinent to the South African context, namely, that of resistance on the part of first-line white managers who may feel that their jobs are threatened. Jones argues that open channels of communication facilitate the intercession of a disinterested party if the black trainee finds a particular situation problematic. Moreover, Jones feels that 'Clear channels of communication will also enable top management to provide empathetic sources of counsel to help the new black trainee combat the potentially crippling paranoia that I encountered. I didn't know whom to trust; consequently, I trusted no one. The counsel of mature and proven black executives will also help mitigate this paranoia' ${ }^{16}$

Thus, the challenge for business is clear; effective delegation, communication, control and feedback should not only improve profitability and motivation generally, but also solve some of the problems associated with 
cultural differences, thereby facilitating the movement of black people into supervisory and middle management and realistically alleviating some of the problems associated with equal pay for equal work (components 3 , 4 and 6 on the crisis axis of the matrix).

\section{Union negotiation}

With respect to negotiations with unions, the challenges for business are both complex and acute. The era of interracial labour competition has left us with a fragmented trade union situation in which the prospect of factionfighting is very real. This, in turn, will not only weaken the ability of organized labour to work towards integration on the basis of merit and ability, but also adds to the problems faced by employers who may become the victims of such faction-fighting. ${ }^{21}$ Moreover, the early eighties may prove to be an era characterized by problems of union recognition and bargaining rights on the one hand and by a high degree of uncertainty on the other. This might, in turn, result in unions employing industrial conflict for political purposes, particularly in view of the exclusion of blacks from the broader political arena. ${ }^{23}$ Although the responsibility for any increased strike activity because of the prevention of access of large groups to the political arena must ultimately rest with the government, the challenge for business lies in the recognition it affords to trade unions, in its ability to participate in industrial relations negotiations and in its clarification of the management of industrial relations at shop-floor level. ${ }^{21}$ An adequate working relationship between business and unions could alleviate some of the problems relating to cultural differences (the 'us, the black workers' versus 'them, the white managers' syndrome), reduce the amount of strike activity and ultimately diminish the shortage of skilled and semi-skilled labour (components 2, 5 and 6 on the crisis axis of the matrix).

\section{Industrial relations}

The personnel management function is usually concerned with the overall control and management of people within the organization whereas industrial relations typically concerns itself with the area of employees' representation through unions, committees and other such bodies. Given the paramount importance of industrial relations to South Africa at present, business should perhaps consider the development of industrial relations as a profession in its own right. Be that as it may, industrial relations is of such critical importance that the challenge for business - or, more specifically, the challenge for management - lies in its role in setting up meaningful industrial-relations policies and procedures. ${ }^{24}$ With respect to black workers, in particular, such policies and procedures could include support of labour-union involvement in community action, ${ }^{25}$ support of group involvement in decision-making and teamwork, ${ }^{26}$ and company involvement in the provision of community facilities. ${ }^{16}$ Such involvement, in turn, by drawing black workers into a more meaningful, or, at least, a more lucrative relationship with the free enterprise system, may lead to a reduction in strike activity, to the alleviation of some of the problems associated with cultural differences and, ultimately, to a greater supply of skilled and semi-skilled labour (components 2, 5 and 6 on the crisis axis of the matrix).

\section{Increased productivity}

The need for a fully-integrated pay structure in labourintensive operations specifically demands increased efficiencies and increased productivity to justify wage increases. In the past, however, this has not been the case. For example, between 1980 and 1981, in the manufacturing sector alone, there was a $20 \%$ increase in wages compared with only a $4 \%$ increase in output per worker. ${ }^{27}$ Moreover, although some capital intensive organizations have been able to eliminate their artificial wage gaps over a relatively short period of time, many labour-intensive operations are in danger of becoming unviable if wage increases are made without a reasonable rise in productivity. The challenge for business is to increase productivity by assisting the black worker to develop a closer or a more meaningful relationship with the free enterprise system. Business could, for example, provide educational and training facilities to encourage the worker to become more skilled; greater skill could lead to more interesting work and to an increase in pay commensurate with each successive increase in skills. Finally, organizations must also attempt to do away with role conflict and role ambiguity, known causes of lower productivity, ${ }^{28}$ not only among their black workers but among all employees. Employees must know where they stand; they must know what is expected of them; they must know what they will receive in return for their labour; and they must know that the organizations in which they work are essentially non-discriminatory and fair. Increased productivity calls for entrepreneurial flair of the highest order which in turn could be achieved by greater delegation and responsibility. Increased productivity in turn could solve some of the problems associated with socio-political wage pressure, could ameliorate intergroup relations and could, ultimately, reduce the shortage of skilled and semi-skilled labour (components 2, 4 and 6 on the crisis axis of the matrix).

The development of strategies and plans to prevent a greater crisis

I have briefly examined six main components of the human resources crisis in South Africa and have thus far put forward 11 major challenges for business with regard to the solution of those crises. I have also attempted to indicate that the components of the crisis and their solutions are interdependent and that they all have to be addressed simultaneously if a crisis is to be averted. I would, however, finally like to suggest an opportunity for business - that opportunity, and perhaps the greatest challenge of all, being the development of strategies and plans to prevent a greater crisis. Business still has the opportunity to develop a consistent and integrated set of strategies and plans to overcome the human resources crisis which at present exists and which can only deteriorate unless positive, constructive action is taken. I have outlined some actions which could be taken to prevent a greater crisis - the rest is up to you. 
Although the focus in this discussion has been mainly on black men, another very important resource must be considered before we develop strategies and plans to avert a worsening of the human resources crisis in the future: the large group of women in all race groups who have so far been underutilized. Many of the problems and challenges mentioned above also apply to many women, particularly stereotypes and cultural differences in the way women were brought up to perceive their own career potential. ${ }^{29}$ But in some other respects, for example educational level and job stability, white, black and coloured women often have been found to have more potential than many black and coloured men. ${ }^{30}$ According to statistics available from the Department of Manpower, the rate at which women in all race groups have moved upwards into professional, managerial and skilled occupations in the 10-year period 1969-79, in all cases exceeded the rate at which men moved into these occupations. This valuable resource must therefore not be overlooked in our overall manpower strategies.

We, in South Africa, must actively work towards a system which functions according to merit and ability regardless of the sex or the race of the individual; which recognizes the need for fair employment practices and which recognizes its obligations to shareholders, to employees and to the country alike. At the moment, we still have the time - the opportunity - to put our house in order and to overcome many of the problems associated with our most valuable asset, our manpower. What no-one should forget, however, is that our time could very quickly run out.

\section{Acknowledgement}

The author gratefully acknowledges the contribution of Dr Linda Human of the SBL to this article, in the form of both background research and compilation of data.

\section{References}

1. Botha, S.P., Minister of Manpower Utilization. Opening Address. In Human, P.G. (Ed.). Industrial Sociology in Human Relations. Pretoria: UNISA, 1981, p.1.

2. National Productivity Institute (NPI). Resource Data. Source material for the Symposium: Manpower Training and Development in the 80s, 1980. See Hofmeyr, K.B. Problems of Black Advancement. Pretoria: UNISA School of Business Leadership, May 1981.

3. Hofmeyr, K.B. Problems of Black Advancement. Pretoria: UNISA School of Business Leadership, May 1981, p.1.1

4. Terblanche, S.S. The Basic Manpower Situation in South Africa. Pretoria: Human Sciences Research Council, SA Institute for Manpower Research, 1979.

5. Swart, S.M. Manpower utilization. S. Afr. J. Labour Relations, 34), Dec. 1979.

6. Dostal, E. Manpower 1975 - 1980: Supply and Demand. Stellenbosch: University of Stellenbosch, Bureau for Economic Research, Unit for Futures Research, 1978 (Newsletter 8/78).

7. Sadie, J. The Quantitative Dimensions of the Labour Problem in South Africa. Pretoria: UNISA, 1980. See Hofmeyr, K.B. Problems of Black Advancement. Pretoria: UNISA School of Business Leadership, May 1981, p.1.2.

8. Mercabank. Focus on Key Economic Issues. November 1980.

9. Parsons, J.A. Employment trends and problems of creating job opportunities in South Africa. Paper presented to NDMF Symposium, June 1977 .
10. Department of Manpower Utilization. Manpower Survey, April 1981.

11. Rosholt, M. Is business really doing enough for SA? Johannesburg: Rand Daily Mail, Jan. 26, 1982, p.11.

12. Allais, A.C. Labour relations - the prime social issue of the 80s. Grahamstown, Rhodes University, Paper presented at the 11 th ASSA Congress, July 1981.

13. See, for example, Mackay, M. Aspects of Upward Occupational Movement of Blacks: Parl I: Problems experienced by both Up. wardly Mobile Individuals and Management: $A$ Brief Review of Relevant Literature. Johannesburg: CSIR, NIPR, CSIR Special Report No: Pers. 303, 1980; Mackay, M. Tabane, M. \& Pooe, E. Aspects of Upward Occupational Movement of Blacks: Part II: Experiences of a Group of Upwardly Mobile Black Managers. Johannesburg, CSIR, NIPR, CSIR Special Report No: Pers. 313, 1980.

14. See, for example, Oosthuizen, G.J., Barnard, A.L. \& Wissing, M.P. Die rol van die blanke werker in die motivering van die swart werker. Perspect. Ind. Psychol., Stellenbosch: University of Stellenbosch, Department of Industrial Psychology, 6(4), 1980, pp.1 - 39 .

15. Nasser, M.E. Need for Achievement: The Base for Effective Managerial Development. Pretoia, University of South Africa, School of Business Leadership, 1981. (Working paper No. 81/04.)

16. See, for example, Human, L.N. The black manager in a white world: A new perspective? S. Afr. J. Labour Relations, 5(2), June 1981, pp.21-27; Human, L.N. Some tentative comments on the black manager in a white world. S. Afr. J. Bus. Mgmt., 12(4), 1981, pp.103-108.

17. Human, L.N. Profiles of managers: A preliminary study. In Human, L.N. \& Van Zyl, M.E. Profiles of Managers in South Africa: Preliminary Readings. Pretoria: UNISA School of Business Leadership, Centre for Management Studies, 1982.

18. Schutte, F.G. Integrated Management Systems. Pretoria: Butterworths, 1981.

19. Van Zyl, M.E. Black enterpreneurs in South Africa: Some preliminary comments. In Human, L.N. \& Van Zyl, M.E. Profiles of Managers in South Africa: Preliminary Readings. Pretoria: UNISA School of Business Leadership, Centre for Management Studies, 1982.

20. See, for example, South African Institute of Race Relations. Education for a New Era. Johannesburg, 1979; Auerbach, F.E. Measuring Educational Development in South Africa. Johannesburg: South African Institute of Race Relations, 1979.

21. Cilliers, S.P. Future social problems in industrial relations. In Human, P.G. (Ed.). Industrial Sociology in Human Relations. Pretoria: UNISA, 1981, pp. 8-16.

22. Jones, E.W. What it's like to be a black manager. Harv. Bus. Rev., July - Aug., 1973, pp. $108-116$.

23. Galin, A. Political and economic determinants of industrial conflict: The case of Israel with possible implications for South Africa. S. Afr. J. Labour Relations, 5(3), Sep. 1981, pp. 5-9.

24. Templer, A.J. Do personnel managers have a say in industrial relations? S. Afr. J. Labour Relations, 5(3), Sep. 1981, pp. $10-17$.

25. Friedman, S. Another new idea at Ford. Johannesburg: Rand Daily Mail, Inside Mail, March 5, 1981, p. 9.

26. Fisher, M.S. Work teams: A case study. Personnel J., Jan. 1981, pp. $42-45$.

27. Figures obtained from the National Productivity Institute, Pretoria, 1982.

28. See, for example, Van Sell, M., Brief, A.P. \& Schuler, R.S. Role conflict and role ambiguity: Integration of the literature and directions for future research. Hum. Relations, 34(1), 1981, pp. $43-71$.

29. Prekel, T. Why a special look at women? S. Afr. J. Bus. Mgmt., 11(2), June 1980, pp. $62-68$.

30. Prekel, T. Women's role in South Africa - and elsewhere. Address at Interota 81 Conference, Vanderbijlpark, Sep. 1981. 